\title{
PENGARUH PENAMBAHAN HERBAFIT DALAM PAKAN TERHADAP KUALITAS FISIK TELUR AYAM RAS PETELUR
}

\section{The Effect of Adding Herbafit on the Physical Quality of Eggs in Laying Hens}

\author{
Nurina Rahmawati ${ }^{* 1)}$, Andri Cahya Irawan ${ }^{1)}$ \\ ${ }^{1}$ Program Studi Peternakan, Fakultas Pertanian, Universitas Islam Kadiri, \\ Jl. Sersan Suharmaji No.38, Manisrenggo, Kediri, Jawa Timur, Indonesia 64128 \\ E-mail: nurinarahmawati90@gmail.com \\ Diterima Pasca Revisi: 24 Februari 2020 \\ Layak Diterbitkan: 1 Maret 2021
}

\begin{abstract}
ABSTRAK
Penelitian ini bertujuan untuk memahami efek herbafit yang ditambahkan dalam pakan tentang kualitas fisik telur ayam ras petelur yang meliputi berat telur, tebal kerabang telur, indeks putih telur, indeks kuning telur, warna kuning telur dan haugh unit telur. Materi penelitian ini berupa ayam ras petelur fase layer dengan strain Isa-Brown umur 28 minggu sebanyak 100 ekor, Fitobiotik (campuran antara tepung kunyit dan jahe dengan rasio masing masing $5: 5: 1$ ), konsentrat ayam petelur, kandang baterai sebanyak 20 kandang. penelitian ini menggunakan metode Rancangan Acak Lengkap (RAL) yang terdiri dari 4 perlakuan dan 5 Ulangan. Perlakuan yang diterapkan yaitu P0 : Pakan Basal (kontrol), P1 : Pakan Basal ditambah Herbafit 1\%, P2 : Pakan Basal ditambah Herbafit 2\%,, P3 : Pakan Basal ditambah Herbafit 3\%. Hasil penelitian menyatakan penambahan herbafit sebanyak $3 \%$ memberikan pengaruh yang nyata $(\mathrm{P}<0,05)$ terhadap tebal kerabang telur, indeks kuning telur, warna kuning telur dan haugh unit telur. Namun penambahan herbafit dengan level $1-3 \%$ tidak memiliki pengaruh $(\mathrm{P}>0,05)$ terhadap berat telur dan indeks putih telur. kesimpulannya adalah penambahan herbafit sebanyak 3\% dalam pakan dapat meningkatkan kualitas fisik telur ayam petelur meliputi kerabang telur, indeks kuning telur, warna kuning telur dan haugh unit.
\end{abstract}

Kata Kunci: Herbafit, kualitas fisik telur, ayam petelur

How to Cite:

N. Rahmawati., \& Irawan, A.C. (2021). Pengaruh Penambahan Herbafit Dalam Pakan Terhadap Kualitas Fisik Telur Ayam Ras Petelur. Jurnal Nutrisi Ternak Tropis 4 (1) 1-14
*Corresponding author:

Nurina Rahmawati

Email: nurinarahmawati90@gmail.com

Program Studi Peternakan, Fakultas Pertanian, Universitas Islam Kadiri, Jl. Sersan Suharmaji No.38, Manisrenggo, Kediri, Jawa Timur, Indonesia, 64128 


\section{ABSTRACT}

The purpose of this study was to determine the effect of adding herbafites to the feed on the physical quality of laying hens' eggs, including egg weight, egg shell thickness, protein index, egg yolk index, egg yolk color and Haugh egg units. The materials for this research were 100 layers of layered chicken with 28-week Isa Brown strain, phytobiotics (a mixture of turmeric flour and ginger in a ratio of 5: 5: 1 each), concentrate from laying hens, 20 battery cages. . The research method used was an experimental method with a fully randomized design (CRD) consisting of 4 treatments and 5 replications. The treatments used were P0: basic forage (control), P1: basic forage plus 1\% Herbafit, P2: basic forage plus 2\% Herbafit, P3: basic forage plus 3\% Herbafit. The results showed that the addition of 3\% Herbafit had a significant effect $(P<0.05)$ on eggshell thickness, egg yolk index, egg yolk color and Haugh egg unit. The addition of herbafits with a content of 1 to $3 \%$ had no significant influence $(P>0.05)$ on the egg weight and the protein index. Based on the results of the study, it can be concluded that adding 3\% herbal feed to the feed can improve the physical quality of laying hens, including eggshells, egg yolk index, egg yolk color, and haugh unit.

Key words: Herbafit, physical quality of eggs, laying hens

\section{PENDAHULUAN}

Kandugan gizi telur dibutuhkan tubuh untuk memenuhi kebutuhan fisiologinya karena telur mengandung protein, lemak, dan karbohidrat serta harganya dapat dijangkau oleh masyarakat. telur ayam memiliki kandungan kimia, yaitu: air $73,6 \%$, protein $12,8 \%$, lemak $11,8 \%$, karbohidrat $1,0 \%$, dan nutrien lainnya $0,8 \%$ (Lesson dan Summer, 2005). Menurut data yang disajikan BPS (2017), rataan masyarakat dalam konsumsi telur pada tahun 2011 sejumlah 0,199 $\mathrm{kg} /$ kapita/minggu sedangkan tahun 2015 sejumlah $1,940 \mathrm{~kg} / \mathrm{kapita} / \mathrm{minggu}$ atau meningkat $8,7 \%$. Kelemahan telur sebagai produk peternakan adalah mudah rusak, rawan crack telur dan mudah terkontaminasi oleh mikroorganisme. menjaga kualitas telur penting dilakukan guna mewujudkan ketahanan pangan, yaitu menyimpan telur di tray agar tidak mudah pecah saat pengiriman dan mempertahankan daya simpan dengan cara memelihara suhu dan kelembaban telur, indikator kualitas eksternal dan internal telur baik adalah segar, cangkang telur bebas dari eacat kotoran, bentuk dan teksturnya cangkang telur baik, isi telur bebas dari mikroba, tidak ada perubahan warna, kuning telur di tengah, dan putih telur tembus cahaya. Indikator penilaian kualitas eksternal telur dapat diuji beberapa metode, contohnya pengukuran berat telur, tebal kerabang, warna kuning telur, indeks putih dan kuning telur. Beberapa faktor yang dapat menentukan kualitas telur adalah manajemen pemeliharaan, kualitas pakan pengaruh penggunaan obat- dalam pakan dan vaksinasi ayam. Salah satu alternatif pengganti obat - obatan kimia yaitu menggunakan tanaman herbal sebagai pengganti antibiotik yang disebut Herbafit. Herbafit terbuat dari bahan herbal/alami seperti tumbuhan. Senyawa aktif dalam Herbafit seperti alkoloid, fenolik, tripenoid, minyak atsiri dan glikosida bersifat sebagai antiviral, antibakteri serta imunomodulator. Bahan pakan yang mengandung senyawa aktif bersifat antiviral, antibakteri serta imunomodulator dapat meningkatkan performa, status kesehatan dan mengurangi penggunaan antibiotic growth promoter (AGP) pada ayam petelur (Andri dkk 2020). Unsur beberapa senyawa aktif tersebut berfungsi untuk menjaga status kesehatan tubuh ayam dan dapat melancarkan peredaran darah. Herbafit dibuat sesuai kepentingan dan fungsinya yang bisa dipilih dari satu jenis atau beberapa jenis tanaman herbal seperti kunyit, jahe, dan daun kelor. Kunyit dapat digunakan sebagai aditif pakan 
untuk ternak unggas. Kunyit sebagai fitobiotik, kunyit diketahui memiliki kemampuan memacu produktifitas ayam broiler dan mengoptimalkan produk yang dihasilkan (Napirah, dkk 2013). Zat kimia utama rimpang kunyit adalah desmetoksikurkumin, lemak, fosfor, kurkumin, minyak atsiri, protein, resin, oleoresin, dan bidesmetoksikurkumin damar, gom, kalsium, dan besi (Shan dan Iskandar, 2018). Tanaman herbal yang mudah didapatkan masyarakat dan produksinya tinggi adalah jahe (Zingiber officinale) termasuk komoditas ekspor (Friska dan Daryono, 2017). Pemberian jahe $0,5 \%$ dapat berfungsi sebagai antioksidan dengan meningkatkan stabilitas oksidatif, tetapi menurunkan kadar kolesterol dalam serum darah ayam pedaging (Zhao dkk 2011). Jahe emprit mengandung $1,5-3,3 \%$ minyak atsiri (Nasiroleslami dan Torki 2010). minyak atsiri mengandung beberapa zat aktif, antara lain: zingeron, shogaol, gingerol, dan antioksidan alami yang berfungsi untuk mencegah dan mengobati penyakit, misalnya: kepala pusing, masuk angin, rematik, impoten, batuk, kanker, pegal-pegal, perut kembung, mabuk perjalanan, Alzheimer, dan penyakit jantung (Aryanta, 2019).

Jahe (Zingiber officinale) terdapat senyawa aktif utama berupa gingerdione, gingerol, dan gingerdiol yang, merangsang enzim pencernaan, dan menjaga keseimbangan aktivitas mikroba baik dalam pencernaan (Asamenew dkk, 2019; Nuraini dkk, 2019; Sjofjan dkk, 2020) Menurut Herawati (2010), penambahan jahe sebanyak $2 \%$ dalam pakan dapat meningkatkan konsumsi (Sjofjan dkk, 2020). Hasil penelitian Adli dkk, (2020), daun kelor memiliki kandungan kalium, $\beta$ karoten, vitamin $\mathrm{C}$, kalsium, protein, dan sumber antioksidan. penambahan tepung daun kelor dalam pakan dapat meningkatkan berat telur dan konsumsi ayam juga menurunkan nilai kolesterol kuning telur dan konversi pakan (Adli, 2020). Menurut Satria dkk (2016), Penambahan tepung daun kelor dalam pakan sebesar 2\% dapat meningkatkan penampilan produksi, kualitas telur ayam petelur dan mampu menurunkan kandungan kolesterol pada kuning telur efek kandungan antioksidan. Menurut Dewi dkk (2014), daun kelor memiliki kandungan protein sebesar $27 \%$ sehingga berkontribusi pada pertambahan berat telur. daun kelor memiliki kadar tanin sebesar 8,22\% (Veronika dkk, 2017). Kadar tanin melebihi $5 \%$ dalam pakan dapat mempengaruhi kadar protein dalam tubuh. Hidayah (2016), senyawa tanin memiliki banyak gugus hidroksi-fenolik yang berpotensi membentuk ikatan silang dengan protein selama di usus halus. Protein dan tanin saling berikatan membentuk senyawa kompleks tanin-protein sehingga protein sangat sulit untuk diabsorpsi dan tidak dapat dihidrolisis oleh protease. Hal ini dikuatkan oleh bukti penelitian Rosini dan Zakir (2016) yang menyatakan bahwa tanin memiliki kemampuan membentuk senyawa kompleks dengan protein selama di dalam usus halus. Ikatan antara tanin dengan protein bersifat sangat kuat sehingga protein tidak mampu dicerna dan diabsorpsi.

Pakan indikator utama yang dapat berpengaruh terhadap produksi dan kualitas telur, umur, kesehatan, manajemen, dan lingkungan. Penambahan feed supplement dalam pakan dapat meningkatkan kualitas telur. Salah satu contoh feed suplement alami adalah ekstrak daun kelor (Moringa oleifera). Suplemen yang berasal dari tanaman herbal sering disebut dengan fitobiotik dan penulis memberikan istilah Herbal Fitobiotik (Herbafit). Penelitian ini bertujuan untuk mengetahui pengaruh penambahan herbafit dalam pakan terhadap kualitas fisik telur ayam ras petelur yang meliputi berat telur, tebal kerabang telur, warna kuning telur, haugh unit telur, indeks putih s dan kuning telur.

\section{METODOLOGI PENELITIAN}

\section{Waktu dan Tempat Penelitian}

Penelitian Lapang dilaksanakan di kandang ayam petelur Desa Tanjung Sepreh, Kec. Maospati, Kab. Magetan, 
tanggal 10 Juli - 08 Agustus 2019. Penelitian Laboratorium dilaksanakan di Laboratorium Terpadu Institut Pertanian Bogor pada tanggal 20 Juni sampai dengan 30 Juni 2019.

\section{Materi Penelitian}

Materi penelitian ini ialah ayam ras petelur fase layer dengan strain Isa-Brown umur 28 minggu sebanyak 100 ekor, Herbafit (campuran antara tepung kunyit dan jahe dengan rasio masing - masing $5: 5$ : 1), konsentrat ayam petelur, kandang baterai sebanyak 20 kandang dengan ukuran panjang x lebar x tinggi yaitu $40 \times 60 \times 40$ $\mathrm{cm} /$ unit. Setiap unit kandang diisi oleh 5 ekor ayam. Tiap unit kandang memiliki tempat pakan dan tempat minum. Peralatan yang digunakan diantaranya alat tulis, lampu sebagai penerangan, timbangan digital kapasitas $500 \mathrm{~g}$, alat pembersih kandang, dan kalkulator.

\section{Metode Penelitian}

Metode penelitian yang digunakan adalah metode percobaan dengan Rancangan Acak Lengkap (RAL) yang terdiri dari 4 perlakuan dan 5 Ulangan yaitu:
P0 : Pakan Basal (kontrol)

P1 : Pakan Basal + Herbafit 1\%

P2 : Pakan Basal + Herbafit 2\%

P3 : Pakan Basal + Herbafit 3\%

\section{Pelaksanaan Penelitian}

1. Pembuatan Fitobiotik

Persiapan bahan seperti tepung kunyit 5 $\mathrm{kg}$, tepung jahe $5 \mathrm{~kg}$ dan tepung daun kelor $1 \mathrm{~kg}$. Pembuatan fitobiotik dengan rasio kunyit : jahe : daun kelor masing masing ialah $5: 5: 1$.

2. Pakan Basal

Penyusunan pakan perlakuan disusun merujuk pada Lesson dan Summers (2005), yaitu pemenuhan kebutuhan nutrien pakan ayam petelur fase developer atau fase pertumbuhan yang sudah menurun sedangkan konsumsi pakan terus bertambah dan fase layer (petelur), memerlukan protein $20 \%$ dan energi metabolis 2900 kkal $\mathrm{kg}^{-1}$. Penelitian ini menggunakan pakan basal terdiri atas konsentrat jadi $40 \%$ : jagung $45 \%$ dan bekatul $15 \%$.

Tabel 1. Susunan Pakan Penelitian

\begin{tabular}{lrrrr}
\hline \multirow{2}{*}{ Jenis Bahan (\%) } & \multicolumn{4}{c}{ Perlakuan } \\
\cline { 2 - 5 } & P0 & P1 & P2 & P3 \\
\hline Konsentrat Jadi & 50 & 50 & 50 & 50 \\
Jagung & 35 & 35 & 35 & 35 \\
Bekatul & 15 & 14 & 13 & 12 \\
Herbafit (kunyit + jahe + daun kelor) & 0 & 1 & 2 & 3 \\
\hline Jumlah & 100 & 100 & 100 & 100 \\
\hline
\end{tabular}

Tabel 2. Hasil Analisis Proksimat Pakan Perlakuan

\begin{tabular}{lrrrr}
\hline \multicolumn{1}{c}{ Kandungan Nutrien } & \multicolumn{4}{c}{ Perlakuan $(\%)$} \\
\cline { 2 - 5 } & \multicolumn{1}{c}{$\mathrm{P} 0$} & $\mathrm{P} 1$ & $\mathrm{P} 2$ & $\mathrm{P} 3$ \\
\hline Bahan Kering & 88,75 & 89,03 & 89,37 & 89,43 \\
Protein Kasar & 19,32 & 19,36 & 19,42 & 19,46 \\
Lemak Kasar & 5,14 & 5,12 & 5,32 & 5,49 \\
Serat Kasar & 4,67 & 4,45 & 4,21 & 4,17 \\
Abu & 11,96 & 12,04 & 12,09 & 12,11 \\
\hline
\end{tabular}

Sumber : Hasil Analisis Laboratorium Terpadu IPB (2019)

3. Penelitian Lapang

Ayam petelur ditempatkan dalam kandang battery kelompok yang diacak dan diberi label, terdiri atas : 4 perlakuan x 5 ulangan x 5 ekor pemberian vitamin dalam air minum bertujuan untuk menggurangi stres pada ayam petelur. Pemeliharaan dilaksanakan dalam 
rentang waktu 28 hari (4 minggu), dimulai umur ayam 28 minggu sampai 32 minggu. Pemberian pakan 120 g/ekor/hari dan air minum diberikan secara ad libitum.

Pemberian pakan dilakukan pada pukul 08.00 WIB dan 15.00 WIB. Setiap hari dilakukan recording, meliputi: pencatatan produksi telur harian, konsumsi pakan, konversi pakan, berat telur, suhu dan kelembaban kandang. pengumpulan telur dilaksanakan setiap hari pukul 09.00 WIB, kemudian ditimbang dan dihitung jumlah telur. Data dicatat setiap hari selama 28 hari (4 minggu).

\section{Kualitas Fisik Telur}

uji kualitas fisik telur dilaksanakan setiap minggu Setiap perlakuan diambil empat butir telur untuk sampel perlakuan.

1. Berat telur $\left(\mathrm{g}\right.$ ekor $\left.{ }^{-1}\right)$. berat telur setiap hari ditimbangan secara digital dengan ketelitian 0,1 g (Purwati dkk 2015) kemudian dihitung rataan setiap perlakuan dan ulangan.

2. Tebal kerabang telur (mm). diukur menggunakan jangka sorong pada bagian tengah (equator), ujung tumpul, dan ujung lancip telur kemudian diratadihitung rataannya.

3. Indeks putih telur (IPT). Memecahkan setiap sampel telur di atas bidang licin dan datar (kaca), kemudian dilakukan pengukuran tinggi dan lebar putih telur menggunakan jangka sorong. perhitungan Indeks Putih Telur disalin pada tabel hasil pemeriksaan. Rumus Indeks putih telur menurut (Fibrianti dkk 2012) adalah :

$$
\frac{\mathrm{T} \quad \mathrm{T}}{1 / 2}
$$

Keterangan:

T: Tinggi Putih Telur; L1: Lebar Putih Telur, L2: Panjang Putih Telur.

4. Indeks kuning telur (IKT). Telur dipecahkan di atas bidang datar dan licin (kaca), kemudian memisahkan bagian putih dan kuning telur Pengukuran tinggi dan lebar kuning telur menggunakan jangka sorong.. perhitungan indeks kuning telur disalin pada tabel hasil pemeriksaan. Rumus Indeks kuning telur menurut Laily dan Suhendra, (1978) adalah :

$$
\text { IKT }=\frac{\text { tinggi kuning telur }(\mathrm{mm})}{\text { diameter kuning telur }(\mathrm{mm})}
$$

5. Warna kuning telur. Pengujian warna kuning telur menggunakan alat egg roche yolk colour fan dengan cara pada membandingkan sampel warna kuning telur dengan kipas standar warna kuning telur.

6. Haugh Unit (HU). Pengukuran tinggi putih telur dengan menggunakan jangka sorong, setelah dilakukan pemecahan telur pada Rumus haugh unit menurut (Yuwanta 2010) adalah :

$\mathrm{HU}=\log 100\left(\mathrm{H}-1,7 \mathrm{~W}^{0,37}+7,57\right)$

Keterangan:

$\mathrm{H}=$ tinggi putih telur $(\mathrm{mm}), \mathrm{W}=$ bobot berat telur ( $\mathrm{g}$ butir $\left.{ }^{-1}\right)$

Hasil nilai HU: >72 = kualitas AA, 60-72 $=$ kualitas A, 31-60 = kualitas B, <31 = kualitas $\mathrm{C}$

\section{Analisis statistik}

Data berat telur, haugh unit, ketebalan kerabang, warna kuning telur, indeks putih dan kuning telur dianalisis menggunakan Rancangan Acak Lengkap yang dilanjutkan dengan uji lanjutan menggunakan Duncan (Alan dkk 2017). Data diolah menggunakan program software komputer Microsoft Excel 2010 dan SPSS Windows versi 21.

\section{HASIL DAN PEMBAHASAN}

Daun kelor dapat bermanfaat untuk digunakan sebagai suplemen pakan yang efektif pada unggas untuk meningkatkan efisiensi pakan pada unggas (Rossida dkk, 2019). Cara kerja utama dari bahan aktif ini adalah penghambatan mikroba patogen dan endotoksin di usus dan peningkatan aktivitas pankreas, menghasilkan metabolisme dan pemanfaatan nutrisi yang lebih baik (Grashorn, 2010). Menurut Mabusela dkk (2018), pemasukan tepung biji kelor oleifera dapat meningkatkan kualitas fisik telur. Beberapa hasil penelitian tentang pengaruh ekstrak herbal pada unggas dilakukan oleh 
Bidura dkk (2017) dan Mohammed dkk (2012), melaporkan bahwa daun kelor dapat meningkatkan produksi telur dan kualitas telur, tetapi menurunkan kolesterol kuning telur pada ayam petelur.

\section{Berat Telur}

pemberian herbafit tidak memiliki pengaruh $(\mathrm{P}>0.05)$ terhadap berat telur ayam petelur (Tabel 2). berat telur terendah terendah terdapat pada penambahan herbafit sebesar $2 \%$ dengan nilai $59.52 \pm 0.77$. berat telur dipengaruhi terutama oleh kandungan protein dalam pakan, faktor genetik, lingkungan, dan umur ayam (Moreki dan Gabanakgosi, 2014). Hal ini dapat menjelaskan tidak ada pengaruh nyata dalam penelitian ini karena semua ayam memiliki umur dan jenis yang sama. Hasil penelitian ini didukung oleh Tasfaye dkk (2014) dan Ahmed dkk (2017) melaporkan bahwa peningkatan level pemberian tepung daun kelor dalam pakan tidak memiliki pengaruh terhadap berat telur, ketebalan cangkang dan indeks bentuk telur. Indikator pakan berkualitas baik adalah terkandung protein, asam amino dan asam linoleat akan mempengaruhi luaran produk (Sjofjan et al., 2020). Hasil penelitian ini bahwa nilai berat telur lebih rendah dibandingkan standar berat telur ayam petelur Isa Brown umur 28 minggu yaitu sebesar $60.8 \mathrm{~g}_{\text {butir }}{ }^{-1}$ (Hendrix Genetic Company, 2015). Prasad dan Ganguly (2012), pemberian daun kelor dalam pakan dapat meningkatkan berat telur dan produksi telur, penyebabnya adalah kandungan senyawa fitokimia pada daun kelor, seperti asam folat, asam askorbat, sumber vitamin A, piridoksin, riboflavin, asam nikotinat, beta-karoten, kalsium, besi, dan $\alpha$-tokoferol. Kandungan protein dalam pakan penelitian ini cenderung sama, sehingga tidak ada perbedaan berat telur yang signifikan antara masing - masing perlakuan (Witantri dkk 2013).

Tabel 3. Pengaruh pemberian fitobiotik dalam pakan terhadap kualitas eksternal telur ayam ras

\begin{tabular}{ccccccc}
\hline Perlakuan & Berat Telur & Tebal Kerabang & Indeks Putih & Indeks Kuning & Warna Kuning & Haugh Unit \\
\hline P0 & $59.73 \pm 0.53$ & $0.36 \pm 0.01^{\mathrm{ab}}$ & $0.15 \pm 0.02$ & $0.40 \pm 0.01^{\mathrm{b}}$ & $6.65 \pm 0.51^{\mathrm{c}}$ & $64.32 \pm 0.98^{\mathrm{b}}$ \\
P1 & $59.98 \pm 0.60$ & $0.37 \pm 0.01^{\mathrm{a}}$ & $0.15 \pm 0.01$ & $0.41 \pm 0.02^{\mathrm{b}}$ & $7.17 \pm 0.41^{\mathrm{bc}}$ & $64.37 \pm 0.57^{\mathrm{b}}$ \\
P2 & $59.52 \pm 0.77$ & $0.35 \pm 0.01^{\mathrm{b}}$ & $0.16 \pm 0.01$ & $0.42 \pm 0.02^{\mathrm{b}}$ & $7.76 \pm 0.50^{\mathrm{ab}}$ & $65.13 \pm 0.97^{\mathrm{b}}$ \\
P3 & $60.08 \pm 0.61$ & $0.35 \pm 0.01^{\mathrm{b}}$ & $0.16 \pm 0.01$ & $0.45 \pm 0.02^{\mathrm{a}}$ & $8.12 \pm 0.51^{\mathrm{a}}$ & $66.76 \pm 0.95^{\mathrm{a}}$ \\
\hline
\end{tabular}

Keterangan : Huruf a,ab,b sebagai superskrip yang berbeda nyata pada baris yang sama menunjukkan perbedaan nyata $(\mathrm{P}<0,05)$.

Menurut Kafi dkk (2017), kunyit memiliki pengaruh terhadap kandungan protein, penyebabnya terdapat antioksidan dalam kunyit yang berfungsi mengurangi stres oksidatif (Tanvir dkk 2017), sehingga dapat menekan gangguan sintesis protein berdampak pada meningkatnya berat telur karena kandungan protein pakan perlakuan lebih tinggi dibandingkan pakan kontrol Kunyit memiliki zat aktif berupa gugus hidroksil yang mudah teroksidasi, sehinggga menguraikan gugus hidrogen dan elektron kepada radikal bebas, kemudian dapat membantu sintesis protein dengan cara menekan produksi (Priyadarsini dkk 2003). Beberapa hasil penelitian melaporkan bahwa pemberian tepung kunyit berpengaruh tidak nyata dalam produksi telur dan kualitas fisik telur (Gumus dkk 2018; Lagana dkk 2011; Zhao dkk 2011) namun dapat meningkatkan berat telur dan ketebalan cangkang (Radwan dkk 2008).

\section{Tebal Kerabang}

pemberian herbafit berpengaruh nyata $(\mathrm{P}<0.05)$ terhadap tebal kerabang dengan rataan nilai sebesar $0.35-0.37$ (Tabel 3). Hasil penelitian menunjukkan bahwa perlakuan penambahan herbafit dengan konsentrasi $1 \%$, 2\% dan 3\% memberikan nilai tebal kerabang telur yang relatif sama.Ketebalan cangkang telur terendah pada perlakuan P3 dikaitkan dengan faktor antinutrisi yang terdapat pada daun kelor yang mengganggu metabolisme kalsium 
(Olugbemi dkk 2010; Paguia dkk 2014). Hasil serupa dilaporkan oleh Tesfaye dkk (2014), yang menunjukkan bahwa parameter kualitas telur seperti haugh unit dan ketebalan cangkang tidak berubah seiring dengan peningkatan kadar kelor dalam pakan, sedangkan efisiensi pakan meningkat. Parameter kualitas telur tetap tidak berubah pada kelompok perlakuan selama periode pemeliharaan dengan suplementasi herfabit (daun kelor) (Gakuya dkk, 2014). Terdapat beberapa hasil penelitian lain melaporkan bertentangan bahwa tanaman yang mengandung senyawa bioaktif, seperti minyak atsiri, flavonoid, dan karotenoid, mempengaruhi haugh unit dan ketebalan cangkang secara positif (Nobakht dan Moghaddam, 2013; Abbas, 2013). Dalam penelitian ini, kami menemukan bahwa nilai tertinggi untuk ketebalan kulit telur pada perlakuan P1 yang diberi pakan rendah lemak yaitu $5.12 \%$. Hal ini didukung hasil penelitian Mirbod dkk (2016) bahwa ketebalan kulit telur lebih baik pada tingkat energi pakan yang rendah dan tingkat kandungan lemak rendah dalam pakan, mengakibatkan peroksidasi lipid yang rendah mengarahkan kurkumin ke selsel uterus untuk meningkatkan fungsi sel sekretori (Radwan dkk 2008). Tepung kunyit dalam pakan mengandung antioksidan alami untuk meningkatkan kinerja sel sekretori uterus, meningkatkan ketebalan kulit telur dan dapat merangsang jalur enzimatik sintesis protein di kelenjar cangkang telur, sehingga meningkatkan kekuatan cangkang telur melalui konsentrasi kolagen dalam matriks cangkang (AlSultan, 2003).

Ketebalan kerabang telur berfungsi untuk menjaga isi telur terhadap benturan dan tekanan dari luar, terutama saat pengumpulan telur, pengiriman telur serta berperan penting dalam melindungi telur dari mikroorganisme yang masuk melalui pori - pori kerabang sehingga mengurangi pembusukan (Tjahjadi dan Marta, 2011). Hartono dkk (2014), penyebab terjadinya peningkatan ketebalan kerabang telur adalah bertambahnya berat kulit kerabang telur karena berkaitan berkorelasi dengan proses pengangkutan. Suplementasi $4-6 \%$ tepung daun kelor dapat meningkatkan daya cerna pakan, warna kuning telur, persentase kuning telur dan cangkang telur, serta ketebalan cangkang pada ayam petelur umur 32 minggu (Siti dkk, 2019).

\section{Indeks Putih Telur}

pemberian herbafit tidak memiliki pengaruh $(\mathrm{P}>0.05)$ terhadap indeks putih telur dengan rataan nilai sebesar $0.15-0.16$ (Tabel 3). Hasil koleksi indeks putih telur selama penelitian tergolong dalam mutu III rataan indeks albumen $0.050-0.091$ (BSN, 2008), penyebabnya adalah masa simpan telur. Jumlah ovomucin dapat menentukan kualitas putih telur ovomucin dibentuk berdasarkan jumlah konsumsi protein (Yuwanta, 2010).

Menurut Kurtini dkk (2014), putih telur banyak mengandung unsur anorganik, seperti kalium bikarbonat dan natrium, telur saat disimpan di suhu kamar akan terjadi penguapan karbondioksida mengakibatkan $\mathrm{pH}$ putih telur meningkat dan berubah menjadi alkalis Kurtini dkk (2014) menambahkan, penyimpanan telur selama 30 hari dapat menurunkan indeks putih telur penyebabnya adalah terjadi kerusakan fisikokimia dari serabut ovomucin efek dari perubahan struktur gel sehingga air keluar dari selaput jala (membran kerabang) dan masuk kuning telur.

\section{Indeks Kuning Telur}

Pemberian herbafit berpengaruh nyata $(\mathrm{P}<0.05)$ terhadap indeks kuning telur dengan rataan nilai sebesar $0.40-0.45$ (Tabel 3). Hal ini mengindikasikan bahwa perlakuan penambahan herbafit dengan konsentrasi $1 \%$, 2\% dan 3\% memberikan nilai indeks kuning telur yang relatif sama. Menurut Lesson dan Summer (2005), indeks kuning telur kondisi segar dalam rentang nilai 0,33-0,50 dengan nilai tataan 0,42. Menurut Argo dan Mangisah (2013), indeks kuning telur dipengaruhi oleh protein, lemak, dan asam amino esensial. Pengujian indeks kuning telur untuk mengetahui mutu kesegaran dari tinggi dan diameter kuning telur (Zita dkk 2013; Gumus dkk 2018). 
Indeks kuning telur menunjukkan terjadinya penurunan progresif dari fungsi membran vitelin pada telur, artinya semakin kecil indeks yolk maka kualitas telur semakin menurun.

Suplementasi daun kelor mempengaruhi produksi telur, massa telur dan senyawa bioaktif kuning telur (Gakuya dkk, 2014). Pemberian kunyit dalam pakan ayam tidak mempengaruhi warna kuning telur dan haugh unit, tetapi secara signifikan meningkatkan indeks kuning telur (Radwan dkk 2008). Antioksidan, flavonoid, karotenoid, asam amino, protein, dan tingkat energi yang mengakibatkan penurunan kadar air telur bisa menjadi alasan peningkatan kepadatan nutrisi pada kuning telur (Gakuya dkk, 2014). Masa simpan telur berkorelasi positif dengan kualitas yolk, semakin lama penyimpanan mengakibatkan serabut ovumucin lemah efek dari kenaikan $\mathrm{pH}$, sehingga sifat membran vitelin yang mudah pecah menjadi kurang elastis dan kehilangan kekuatannya (Kurtini dkk 2014). Warna Kuning Telur

Pemberian herbafit berpengaruh nyata $(\mathrm{P}<0.05)$ terhadap warna kuning telur. Perlakuan P1, P2, dan P3 memiliki warna yang jauh lebih tinggi dibandingkan dengan kontrol. Kenaikan warna kuning telur pada penelitian ini memperlihatkan bahwa daun kelor mengandung banyak vitamin A dan berfungsi sebagai pigmen karotenoid yang mudah diserap dan digunakan oleh ayam. Peningkatan warna kuning tersebut disebabkan oleh kandungan karotenoid pada serbuk daun kelor. Skor warna kuning telur hasil penelitian yaitu berada pada skor ke-8.

Daun kelor kaya kandungan karotenoid dan flavonoid, yang merupakan antioksidan alami kuat yang dapat memodifikasi kadar $\beta$-karoten dan kuersetin kuning telur (Gakuya dkk 2014). Menurut Amaglo (2010); Saini dkk (2014a); dan Saini dkk (2014b), $\beta$-karoten dalam daun kelor berkisar dari 2.7-310 mg/100 g kering. Ketika ditambahkan ke pakan, bioaktif ini bersama dengan fitokimia meningkatkan produksi telur dan berdampak positif bagi kesehatan ayam. Karotenoid berperan penting dalam perkembangan skor warna yang berbeda pada kuning telur. Terutama, lutein adalah pewarna kuning aktif. Penggunaan daun kelor $10-20 \%$ dalam pakan atau bertelur ayam pedaging dapat meningkatkan warna kuning pada kulit dan kuning telur secara signifikan (Olugbemi dkk 2010). Menurut Riasi dkk (2012) bahwa pigmen kekuningan pada kunyit (kurkuminoid, kurkumin, dan senyawa terkait) dapat sedikit memperbaiki warna kuning telur. Nuraini dkk (2019) melaporkan bahwa penambahan $2 \%$ rimpang kunyit pada pakan ayam petelur dapat meningkatkan skor warna kuning telur 7-9. Penggunaan kurkumin juga dapat meningkatkan warna kulit ayam disebabkan oleh pigmen tersimpan di dalam kulit ayam petelur (Radwan dkk 2008). warna kuning telur responsif terhadap-kurkumin dari kunyit, sehingga dapat meningkatkan zat warna kuning alami terhadap pada kuning telur seiring penambahan level kunyit dalam pakan. level herbafit 3\% (P3) memiliki nilai rataan warna kuning telur paling tinggi sebesar $8.12 \pm 0.51$.

\section{Haugh Unit}

pemberian herbafit berpengaruh nyata $(\mathrm{P}<0.05)$ terhadap haugh unit telur dengan rataan nilai sebesar 64.32 - 66.76 (Tabel 3). Haugh unit telur dalam penelitian ini menunjukkan perlakuan P0 dan P1 tergolong mutu I dengan nilai $\mathrm{HU}>72$, P2 dan P3 tergolong mutu II dengan nilai HU 62-72 (SNI, 2006). Pengujian haugh unit telur berkorelasi positif dengan kualitas telur segi kesegaran (Riawan dkk 2017). Hasil penelitian ini menunjukkan seiring penambahan level tepung daun kelor mengakibatkan nilai HU menurun.

Pengujian haugh unit telur bertujuan untuk mengetahui tingkat kesegaran kesegaran internal telur dan putih telur (Selim dkk 2018). Hasil penelitian ini mengungkapkan bahwa perlakuan penambahan herbafit memiliki nilai haugh unit lebih tinggi dibandingkan perlakuan kontrol (P0). Faktor penyebab nilai HU rendah berkaitan erat dengan kandungan ovomucin dalam telur yang menipis 
(Stadelman dan Cotteril, 1995). Beberapa indikator yang menentukan nilai HU pada ayam petelur ialah masa simpan, umur, nutrien pakan, tempat penyimpanan telur, strain, penyakit suplementasi vitamin $\mathrm{C}$ dan atau E (Ahmadi dan Rahmini 2011), molting, lama penyimpanan (Roberts 2004), tinggi albumen dan bobot berat telur (Stadelman dan Cotterill 1995). Menurut USDA (2000), menambahkan jika HU telur dengan kualitas AA $(72-100)$, B (60 - 71), C (>29). Semua telur dengan penyimpanan suhu dibawah $8^{\circ} \mathrm{C}$ diklasifikasikan AA atau sangat baik.

\section{KESIMPULAN}

Pemberian herbafit sebanyak 3\% dalam pakan (P3) dapat meningkatkan kualitas telur ayam ras meliputi indeks kuning telur, kerabang telur, haugh unit dan warna kuning telur.

\section{DAFTAR PUSTAKA}

Abbas, T. E. (2013). The use of Moringa oleifera in poultry diets. Turkish Journal of Veterinary and Animal Sciences, 37(5), 492-496. https:// doi.org/10.3906/vet-1211-40.

Adli, D. N., dan Sjofjan, O. (2020). MetaAnalisis: pengaruh substitusi jagung dengan bahan pakal lokal terhadap kualitas karkas daging broiler. Jurnal Ilmu Peternakan Terapan, 3(2), 44-48.

Adli, D. N., dan Sjofjan, O. (2020). Estimasi dan Validasi Kandungan Energi Bekatul Sebagai Pakan Unggas dari Komposisi Kimia Pakan. Jurnal Nutrisi Ternak Tropis, 3(2), 90-96.

Adli, D. N. (2020). Growth performance, and blood profile of kampong chicken fed diets containing Moringa oleifera powder and liquid. Asian Journal of Agriculture, 4(2).

Adli, D. N., Sjofjan, O., dan Mashudi, M. (2018). Nutrient content evaluation of dried of poultry waste urea-molasses block (dpw-umb) on proximate analysis. Jurnal Ilmu dan Teknologi Peternakan, 6(2), 72-76.

Ahmadi, F., \& Rahmini, F. (2011). Factors affecting quality and quantity of egg production in laying hens: a review. World Applied Sciences Journal, 12(3), 327-384.

Ahmed, S., Khalique, A., Pasha, T. N., Mehmood, S., Hussain, K., Ahmad, S., Shaheen, M. S., Naeem, M., \& Shafiq, M. (2017). Effect of Moringa oleifera (Lam.) pods as feed additive on egg antioxidants, chemical composition and performance of commercial layers. South African Journal of Animal Science, 47(6), 864-874. https://doi.org/10.4314/saja s.v47i6.14

Alan, A., Christine, F., \& Bernhard, K. (2017). Statistics: The Art and Science of Learning from Data 4nd ed. London: Pearson Education Limited.

Al-Sultan S. I. (2003). The effect of Curcuma longa (Tumeric) on overall performance of broiler chickens. International Journal of Poultry Science, 2(5), 351-353. https://doi. org/10.3923/ijps.2003.351.353.

Amaglo, N. K., Bennett, R. N., Curto, R. B., Rosa, E. A., Turco, V. L., \& Giuffrida, A. (2010). Profiling selected phytochemicals and nutrients in different tissues of the multipurpose tree Moringa oleifera L., grown in Ghana. Food Chemistry, 122(4), 1047-1054. https://doi.org/10.1016/j. foodchem.2010.03.073.

Argo, L. B. \& Mangisah. (2013). Kualitas Fisik Telur Ayam Arab Petelur Fase 1 Dengan Berbagai Level Azolla microphylla. Animal Agricultural Journal, 2(1), 445-457.

Aryanta, I. W. R. (2019). Manfaat Jahe untuk kesehatan. E-Jurnal Widya Kesehatan, 1(2), 39-43. https://doi.or $\mathrm{g} / 10.32795 /$ widyakesehatan.v1i2.463.

Asamenew, G., Kim, H. W., Lee, M. K., Lee, S. H., Kim, Y. J., Cha, Y. S., Yoo, S. M., \& Kim, J. B. (2019). Characterization of phenolic 
compounds from normal ginger (Zingiber officinale Rosc.) and black ginger (Kaempferia parviflora Wall.) using UPLC-DAD-QToF-MS. European Food Research and Technology, 245, 653-665. https:// doi.org/10.1007/s00217-018-3188-z.

Badan Pusat Statistik (BPS). (2017). Konsumai Bahan Pokok Nasional.

Badan Standar Nasional (BSN). (2008). Telur Ayam Konsumsi. SNI 3926:2008 Jakarta: Standar Nasional Indonesia.

Bidura, I. G. N. G., Partama, I. B. G., Putri, B. R. T., \& Watiniasih, N. (2017). Effect of Water Extract of Two Leaves (Allium sativum and Sauropus androgynus) on Egg Production and Yolk Cholesterol Levels in Egg Laying Hens. Pakistan Journal of Nutrition, 16(7), 482-487. https://doi. org/10.3923/pjn.2017.482.487.

Danung, N. A., Sjofjan, O., dan Mashudi, M. (2018). Nutrient content evaluation of dried of poultry waste urea-molasses block (dpw-umb) on proximate analysis. Jurnal Ilmu dan Teknologi Peternakan, 6(2), 72-76.

Dewi, T., Bidura, I. G. N. G., \& Candrawati, D. P. M. A. (2014). Pengaruh Pemberian Ekstrak dan Kelor (Moringa oleifera) dan Bawan Putih (Allium sativa) Melalui Air Minum terhadap Penampilan Broiler Umur 26 Minggu. E-Jurnal Peternakan Tropika, 2(2), 252-261.

Fibrianti, S. M., I Ketut, S., \& Rudyanto, M. D. (2012). Kualitas Telur Ayam Konsumsi yang Dibersihkan dan Tanpa Dibersihkan Selama Penyimpanan Suhu Kamar. Indonesia Medicus Veterinus, 1(3), 408-416.

Friska, M. \& Daryono, B. S. 2017. Karakter Fenotip Jahe Merah (Zingiber officinale var. rubrum) Hasil Poliploidisasi Dengan Kolkisin. Journal of Biology, 10(2), 91-97. http//:dx.doi.org/10.15408/kauniyah.v $10 \mathrm{i} 2.4813$.
Gakuya, D. W., Mbugua, P. N., Mwaniki, S. M., Kiama, S. G., Muchemi, G. M., \& Njuguna, A. (2014). Effect of supplementation of Moringa oleifera (LAM) leaf meal in layer chicken feed. International Journal of Poultry Science, 13(7), 379-384. https://doi. org/10.3923/ijps.2014.379.384.

Grashorn, M. A. (2010). Use of Phytobiotics in Broiler Nutrition-An Alternative to in Feed Antibiotics? Journal of Animal and Feed Sciences, 19, 338347. https://doi.org/10.22358/jafs/66 297/2010.

Gumus, H., Oguz, M. N., Bugdayci, K. E., \& Oguz, F. K. (2018). Effects of Sumac and Turmeric as Feed Additives on Performance, Egg Quality Traits, and Blood Parameters of Laying Hens. Revista Brasileira de Zootecnia, 47, 11-22. https://doi.org/ 10.1590/rbz4720170114.

Hartono T. A., Puger, A. W., \& Nuriyasa, I. M. (2014). Kualitas Telur Lima Jenis Ayam Kampung Yang Memiliki Warna Bulu Berbeda. E-Journal Peternakan Tropika, 2(2), 153-162.

Hendrix Genetic Company. (2015). Isa Brown Management Guide. Peterborough (UK): A Hendrix Genetic Company.

Herawati. 2010. The Effect of feeding red ginger as phytobiotic on body weight gain, feed conversion and internal organs condition of broiler. International Journal of Poultry Science, 9(10), 963-967. https://doi. org/10.3923/ijps.2010.963.967.

Hidayah, N. 2016. Pemanfaatan Senyawa Metabolit Sekunder Tanaman (Tanin dan Saponin) dalam Mengurangi Emisi Metan Ternak Ruminansia. Jurnal Sain Peternakan Indonesia, 11(2), 89-98. https://doi.org/10.31186 /jspi.id.11.2.89-98.

Irawan, A. C., Astuti, D. A., Wibawan, I. W. T., \& Hermana, W. (2020). Supplementation of black soldier fly (Hermetia illucens) on productivity and blood hematology. Jurnal Ilmu- 
Ilmu Peternakan, 30(1), 50-68. https://doi.org/10.21776/ub.jiip.2020. 030.01.06.

Kafi, A., Uddin, Md., N., Uddin, J., Khan, M., \& Haque, M. E. (2017). Effect of Dietary Supplementation of Turmeric (Curcuma longa), Ginger (Zingiber officinale) and their Combination as Feed Additives on Feed Intake, Growth Performance and Economics of Broiler. International Journal of Poultry Science, 16(7), 257-265. https ://doi.org/10.3923/ijps.2017.257.265.

Krisnadi, A. D. (2015). Kelor Super Nutrisi. Blora: Pusat Informasi dan Pengembangan Tanaman Kelor Indonesia.

Kurtini, T., K. Nova, \& D. Septinova. (2014). Produksi Ternak Unggas Edisi Revisi. Bandar Lampung: Aura Printing dan Publishing.

Lagana, C., Pizzolante, C. C., Saldanha, E., \& Moraes, J. E. (2011). Turmeric Root and Annato Seed in Second-Cycle Layer Diets: Performance and Egg Quality. Br azilian Poultry Science, 13(3), 171-176. https://doi.org/10.15 90/S1516-635X2011000300002.

Laily, R. A., \& Suhendra, P. (1978). Teknologi Hasil Ternak. Bagian II. Teknologi Telur. Edisi ke-2. Ujung Pandang: Lephas.

Lesson, S., \& Summer, J. D. (2005). Comercial Poultry Nutrition 3rd edition. Canada: University Guelph.

Mabusela, S. P., Nkukwana, T. T., Mokoma, M., \& Muchenje, V. (2018). Layer performance, fatty acid profile and the quality of eggs from hens supplemented with Moringa oleifera whole seed meal. South African Journal of Animal Science, 48(2), 234-243. https://doi.org/10.4314/saja s.v48i2.4.

Mirbod, M., Mahdavi, A. H., Samie, A. H., \& Mehri, M. (2016). Effects of Curcuma longa rhizome powder on egg quality, performance, and some physiological indices of laying hens fed different levels of metabolizable energy. Journal of the Science of Food and Agriculture, 97(4), 1-29. https:// doi.org/10.1002/jsfa.7862.

Mohammed, K. A. F., Sarmiento, F. L., Santos, R. R, \& Solorio, S. J. F. (2012). The nutritional effect of Moringa oleifera fresh leaves on Rhode Island Red hen egg production and quality. Tropical Animal Health and Production, 44(5), 1035-1040. https://doi.org/10.1007/s11250-011-0 037-5.

Moreki, J. C., \& Gabanakgosi, K. (2014). Potential use of moringa oleifera in poultry diets. Global Journal of Animal Scientific Research, 2(2), 109-115.

Napirah, A., Supadmo, \& Zuprizal. (2013). Pengaruh penambahan tepung kunyit (Curcuma domestica Valet) dalam pakan terhadap parameter hematologi darah puyuh (Coturnix-coturnix japonica) pedaging. Buletin Peternakan, 37(2), 114-119. https:// doi.org/10.21059/buletinpeternak.v37 i2.2429.

Nasiroleslami, M., \& Torki, M. (2010). Including Essential Oils of Fennel (Foeniculum Vulgare) and Ginger (Zingiber Officinale) to Diet and Evaluating Performance of Laying Hens, White Blood Cell Count and Egg Quality Characteristics. Advances in Environmental Biology, 4(3), 341-345.

Nobakht, A., \& Moghaddam, M. (2013). The effects of different levels of costmary (Tanacetum balsamita) medicinal plant on performance, egg traits and blood biochemical parameters of laying hens. Iranian Journal of Applied Animal Science, 3(2), 307-312.

Nuraini, Mirzah \& Djulardi, A. (2019). Effect of Turmeric (Curcuma domestica, Val) Extract as a Feed Additive on Performance and Egg Quality of Quail. International Journal of Poultry Science, 18(2), 8892. https://doi.org/10.3923/ijps.2019. 88.92. 
Olugbemi, T. S., Mutayoba, S. K., \& Lekule, F. P. (2010). Effect of Moringa (Moringa oleifera) inclusion in cassava based diets fed to broiler chickens. International Journal of Poultry Science, 9(4), 363-367. https: //doi.org/10.3923/ijps.2010.363.367.

Paguia, H. M., Paguia, R. Q., Balba, C., \& Flores, R. C. (2014). Utilization and evaluation of Moringa oleifera $\mathrm{L}$. as poultry feeds. 4th International Conference on Agriculture and Animal Science, 8, 343-347. https:// doi.org/10.1016/j.apcbee.2014.03.051

Prasad, A., \& Ganguly, S. (2012). Promising medicinal role of Moringa oleifera: a review. Journal of Immunology and Immunopathology, 14(1), 1-5. https:// doi.org/10.5958/j.0972-0561.14.1.001.

Priyadarsini, K. I., Maity, D. K., Naik, G. H., Kumar, M. S., Unnikrishnan, M. K., Satav, J. K., \& Mohan, H. (2003). Role of phenolic O-H and methylene hydrogen on the free radical reactions andantioxidant activity of curcumin. Free Radical Biology and Medicine, 35(5), 475-484. https://doi.org/10. 1016/S0891-5849(03)00325-3.

Purwati, D., Djaelani, M. A., \& Eny, Y. W. Y. (2015). Indeks kuning telur (IKT), haugh unit (HU) dan bobot telur pada berbagai itik lokal di jawa tengah. Jurnal Biologi, 4(2), 1-9.

Radwan, N. L., Hassan, R. A., Qota, E. M., \& Fayek, H. M. (2008). Effect of natural antioxidant on oxidative stability of eggs and productive and reproductive performance of laying hens. International Journal of Poultry Science, 7(2), 134-150. https://doi. org/ 10.3923/ijps.2008.134.150.

Riasi, A., Kermanshahi, H., \& Mahdavi, A. H. (2012). Production performance, egg quality and some serum metabolites of older commercial laying hens fed different levels of turmeric rhizome (Curcuma longa) powder. Journal of Medicinal Plants Research, 6(11), 2141-2145. https:// doi.org/10.5897/JMPR11.1316.
Riawan, Riyanti \& Nova, K. (2017). Pengaruh Perendaman Telur Menggunakan Larutan Daun Kelor Terhadap Kualitas Internal Telur Ayam Ras. Jurnal Ilmiah Peternakan Terpadu, 5(1), 1-7. https://doi.org/ 10.23960/jipt.v5i1.p1-7.

Roberts, J. R. (2004). Factors affecting eggs internal quality and egg shell quality in laying hens. The Journal of Poultry Science, 41(3), 161-177. https://doi. org/10.2141/jpsa.41.161.

Rosini, T., \& Zakir, I. (2016). Performans Produk, Jumlah Nematoda Usus, dan Profil Metabolik Darah Kambing yang Diberi Pakan Hijauan Rawa Kalimantan. Jurnal Veteriner, 18(3), 469-477. https://doi.org/10.19087/jv eteriner.2017.18.3.469.

Rossida, K. F. P., Sunarno, Kasiyati, \& Djaelani, M. A. (2019). Pengaruh imbuhan tepung daun kelor (Moringa oleifera Lam.) dalam pakan pada kandungan protein dan kolesterol telur itik pengging (Anas platyrhyncos domesticus L.). Jurnal Biologi Tropika, 2(2), 41-47. https://doi.org/ 10.14710/jbt.2.2.41-47.

Saini(a), R. K., Shetty, N. P., Prakash, M., \& Giridhar, P. (2014). Effect of dehydration methods on retention of carotenoids, tocopherols, ascorbic acid and antioxidant activity in Moringa oleifera leaves and preparation of a RTE product. Journal of Food Science and Technology, 51(9), 2176-2182. https://doi.org/10. 1007/s13197-014-1264-3.

Saini(b), R. K., Shetty, N. P., \& Giridhar, P. (2014). Carotenoid content in vegetative and reproductive parts of commercially grown Moringa oleifera Lam. cultivars from India by LCAPCI-MS. European Food Research and Technology, 238(6), 971-978. https://doi.org/10.1007/s00217-0142174-3.

Satria, E. W., Osfar, S., \& Irfan, H. D. (2016). Respon Pemberian Tepung Daun Kelor (Moringa oleifera) pada 
Pakan Ayam Petelur terhadap Penampilan Produksi dan Kualitas Telur. Buletin Peternakan, 40(3), 197202. https://doi.org/10.21059/ buletin peternak.v40i3.11203.

Selim, S., Hussein, E., \& Abou, E. R. (2018). Effect of spirulina platensis as a feed additive on laying performance, egg quality and hepatoprotective activity of laying hens. European Poultry Science, 82, 1-13. https://doi.org/10.1399/eps.2018.227.

Shan, C. Y. \& Iskandar, Y. (2018). Studi Kandungan Kimia Dan Aktivitas Farmakologi Tanaman Kunyit (Curcuma longa L.) Jurnal Farmaka, 16(2), 547-555. https://doi.org/10.24 198/jf.v16i2.17610.g8793.

Sjofjan, O., Adli, D. N., Djunaidi, I., and Kuncoro, K. (2020). Utilization of Biogas Liquid Waste For Starter In The Fermentation of Rice Husk As A Potential Feed For Poultry. Animal Production, 22(1), 24-30.

Sjofjan, O., Adli, D. N., Natsir, M. H., dan Kusumaningtyaswati, A. (2020). Pengaruh kombinasi tepung kunyit (Curcuma domestica Val.) dan probiotik terhadap penampilan usus ayam pedaging. Jurnal Nutrisi Ternak Tropis dan Ilmu Pakan, 2(1).

Siti, N. W., Bidura, I. G. N. G., Mayuni, S. N., Suasta, I. M., \& Utami, I. A. P. (2019). Effect of Moringa oleifera leaf powder in diets on feed digestibility and external egg quality characteristics in laying hens. International Journal of Fauna and Biological Studies, 6(4), 113-118. https://doi.org/10.1088/1757-899X/ 823/1/012006.

Stadelman, W. J., \& O. J. Cotteril. (1995). Egg Science and Technology 4th Ed. New York: Food Products Press. An Imprint of the Haworth Press, Inc.

Tanvir, E. M., Hossen, Md. S., Hossain, Md. F., Afroz, R., Gan, S. H., Khalil, Md. I., \& Karim, N. (2017). Antioxidant Properties of Popular Turmeric (Curcuma longa) Varieties from
Bangladesh. Journal of Food Quality, 3, 1-8. https://doi.org/10.1155/2017/ 8471785.

Tesfaye, E. B., Animut, G. M., Urge, M. L., \& Dessie, T. A. (2014). Cassava root chips and Moringa oleifera leaf meal as alternative feed ingredients in the layer ration. The Journal of Applied Poultry Research, 23(4), 614-624. https://doi.org/10.3382/japr.2013-00 920.

Tjahjadi, C., \& Marta, H. 2011. Buku Ajar Pengantar Teknologi Pangan Volume II. Universitas Padjadjaran, Jatinangor.

Unites States Departement of Agriculture (USDA). (2000). Egg grading Manual. Departament of Agriculture, Washington.

Veronika, M., Purwijatiningsih, E. W., \& Pranata, S. (2017). Efektivitas Ekstrak Daun Kelor (Moringa oleifera) sebagai Bio-Sanitizer Tangan dan Daun Selada (Lactuca sativa). Master thesis. University of Atma Jaya, Department of Technobiology.

Witantri, H., Suprijatna, E., \& Sarengat, W. (2013). Pengaruh Penambahan Tepung Jahe Merah (Zingiber officinale var. Rubrum) dalam Pakan terhadap Kualitas Telur Ayam Kampung Periode Layer. Animal Agriculture Journal, 2(1), 478-488.

Yuwanta, T. (2010). Telur dan Kualitas Telur. Yogyakarta: Gadjah Mada University Press.

Zhao, X., Yang, Z. B., Yang, W. R., Wang, Y., Jiang, S. Z., \& Zhang, G. G. (2011). Effects of Ginger Root (Zingiber officinale) on Laying Performance and Antioxidant Status of Laying Hens and on Dietary Oxidation Stability. Poultry Science, 90(8), 1720-1727. https://doi.org/ 10.3382/ps.2010-01280.

Zita, L., Ledvinka, Z., \& Klesalová, L. (2013). The effect of the age of Japanese quails on certain egg quality traits he effect of the age of Japanese quails on certain egg quality traits and 
their relationships. Veterinary Archives, 83(2), 223-232. 